\title{
IgM Antibody Secreting Cell Count
}

National Cancer Institute

\section{Source}

National Cancer Institute. IgM Antibody Secreting Cell Count. NCI Thesaurus. Code C132362.

The determination of the number of IgM antibody-secreting cells in a biological sample. 